\title{
箱形断面梁の圧縮とねじりの複合荷重時の座屈応力関係式
}

古巣 克也 ${ }^{* 1}$, 尼子 龍幸 ${ }^{* 1}$, 中川 稔章*1, 浜辺 勉 ${ }^{* 2}$, 青木 典久 ${ }^{* 2}$

\section{Buckling stress relation equations of box beam under compression and torsion}

\author{
Katsuya FURUSU*1, Tatsuyuki AMAGO*1 ${ }^{* 1}$ Toshiaki NAKAGAWA*1, \\ Tsutomu HAMABE ${ }^{* 2}$ and Norihisa $\mathrm{AOKI}^{* 2}$ \\ ${ }^{* 1}$ Metal-Processing and Strength Modeling Lab., Toyota Central Research and Development, Inc. \\ 41-1 Yokomichi, Nagakute-shi, Aichi 480-1192, Japan \\ ${ }^{* 2}$ Vehicle Engineering Development Div., Toyota Motor Corporation \\ 1 Toyota-cho, Toyota-shi, Aichi 471-8572, Japan
}

\section{Received 11 April 2014}

\begin{abstract}
Recently, high strength steel is used increasingly for plates which constitute the frame structures of vehicles. Since these plates become thinner, the buckling on the plates has been recognized as an important issue for automotive industries. For this issue, various methods have been proposed and are currently in practical use. In this paper, the buckling stress relation equations of the plate are discussed which is the basis of buckling analysis of a structure, and on the basis of the buckling stress relation equation of a single plate, the relation equation of compression and shear is shown under axis compression force and twisting torque on the box beam composed by thin plates. And, the approximate expression for the compression buckling stress is proposed by the knowledge of the buckling eigenvalue equation by the energy method and the approximate expression of the twisting. The accuracy of the approximate expression and relation equation is investigated as compared with the results from the buckling eigenvalue analysis by FEM. As the results, well-known relation equations of the plates can be obtained by approximating the buckling eigenequations by the energy method assuming the deformed shape function with low-order terms. Also the compression buckling stress of the box beam determined by a single plate theory does not have enough accuracy, and it is necessary to consider the coupling with adjacent plates. The difference between the proposed expression and results by FEM is less than about $6 \%$ for the aspect ratio of the cross section between 0.3 and 1.0. And then, the shown buckling stress relation equation of compression and torsion has up to $12 \%$ difference from the results by FEM.
\end{abstract}

Key words : Buckling, Compression, Shear, Torsion, Shell structure, Box beam, FEM, Energy method

\section{1. 緒言}

自動車車体の静的強度や衝突性能を考慮した初期設計において, 従来から骨格を構成する断面の全塑性力を評 価し断面形状を決定する方法が用いられていた（Nishigaki, et al., 2001）。この全塑性力による評価尺度では，断面 を構成する鋼板が全て有効に活用され，全鋼板が降伏応力状態になるところを耐力としていた．近年の自動車車 体では, 強度を保ちつつ軽量化するために高強度鋼板の利用が進み, それに伴い骨格構造の薄板化が進んでいる. このような薄板で構成された骨格構造に様々な外力が作用する場合, 上述の全塑性力に代わる評価方法が必要と されており，様々な方法が提案され，現在実用されている.

No.14-00208 [DOI: 10.1299/transjsme.2014smm0219]

*1 正員, (株) 豊田中央研究所 (厂480-1192 愛知県長久手市横道 41-1)

*2 トヨタ自動車（广471-8572 愛知県豊田市卜ヨタ町 1 番地）

E-mail of corresponding author: furusu@mosk.tytlabs.co.jp 
例えば，薄板化に伴い弾性座屈が発生するが（林, 1966, Timoshenko, 1961），この現象を解析する方法の一つと して弾性座屈を考慮した有効幅理論がある (Karman, et al., 1932, Yu, 2000)。その解説文献や解析機能を有するソ フトウェア（AISI/CARS 2002, 2002, CARS manual, 2002）が市販されており，弾性座屈を考慮して耐力を見積もる 方法が多く提案されている．またこれまでに，著者らも単純支持の長方形平板や箱形断面の梁の曲げや圧縮にお ける有効幅について検討してきた（古巣他, 2004, 古巣他, 2006)。さらに，有限要素法（FEM）を代表とする計算 支援技術を利用して，剛性や強度を実用的に評価している。

車体の骨格構造には，曲げや圧縮荷重のみならず，㸚じりトルクも加わる．しかし，従来の有効幅理論は基本 的には曲げや圧縮荷重を対象としたものであり，任意の外力に対応するためにはねじりトルクに対して有効幅理 論と同様な考え方が必要となる，そこで筆者らは，縮小因子を定義しそれを基にして，㸚じり耐力を求めるため の基礎となる平板のせん断座屈後挙動の計算式を導出した（古巣他, 2011, 2012a). そして箱形断面梁に関して, ねじり座屈時のせん断応力を求める近似式を提案した（古巣他, 2012b, 2013a, 2013b).

さらに，任意の外力に対する座屈後挙動や耐力を求めるためには，圧縮荷重，曲げモーメント，ねじりトルク が複合した場合の座屈現象を把握する必要がある. 複合荷重が作用する場合の平板に関する座屈応力関係式は, 多くの書籍（Ziemian, 2010, 宇佐美編, 2005）に記載されている．しかし，これらの関係式の多くは，主として平 板の座屈の基礎方程式から求められた厳密解の回帰式として求められており, その導出の手順がはっきりとして いないものがある.さらにまた, 箱形断面梁のような複数の平板で構成された構造物の場合, 単一平板と異なり, 隣り合う面との連成を考慮する必要があるため, 平板の結果をそのまま適用することが難しい.

そこで本論文では，箱形断面梁に任意外力が作用する場合の座屈解析の端緒として，平板における座屈応力関 係式に関して考察する．エネルギー法により得られる座屈固有方程式を低次数の項で近似することにより公知の 関係式が得られることを示し，それらの公知の関係式の類似性に言及する. 次に, 箱形断面梁の軸方向圧縮力と ねじりトルクが複合する場合の圧縮とせん断の座屈応力関係式を提案する. ただし, 前述の通り, 箱形断面梁の 軸圧縮における圧縮座屈応力に関して, これまで隣り合う面との連成を考慮した座屈解析の例が見当たらないた め，その近似解法も提案する．そして，これらの提案した式を FEMによる結果と比較し，式の妥当性を示す.

なお，弾性座屈やそれに伴う非線形挙動は，FEMに代表される数值解法を用いることにより，高精度な結果を 得ることが可能であるが，見通しのよい理論解，近似解を示すことは以下の点で意義の高いことと考える．すな わち, 設計の初期段階においては, FEM 等の数值解析を利用するための形状が確定していないことが多いため, 形状を確定させるための理論解や近似解による骨格の耐力の見積もりが，素性の良い設計案の創出に非常に重要 である. また，座屈に関する工学的な理解，FEM 等の数值解析による解の妥当性検証において有用である.

\section{2. エネルギ一法に基づく複合応力時の座屈応力関係式の導出}

\section{$2 \cdot 1$ 平板における座屈応力の公知の基礎式}

本章では, 図 1 に示寸ような長さ $l$, 幅 $b$, 板厚 $t$ の薄板で構成された四辺単純支持境界の長方形平板（ヤング 率を $E$, ポアソン比を $\mu$ ）を対象に考える. このような長方形平板に, 図のように, 圧縮応力 $\sigma$, せん断応力 $\tau$, 曲 げ応力 $\sigma_{B}$ が作用するとき，それぞれ単独で作用寸る場合の座屈応力 $\hat{\sigma}_{c r}, \hat{\tau}_{c r}, \hat{\sigma}_{B c r}$ は以下の通りである（林, 1966, Timoshenko, 1961, Ziemian, 2010).

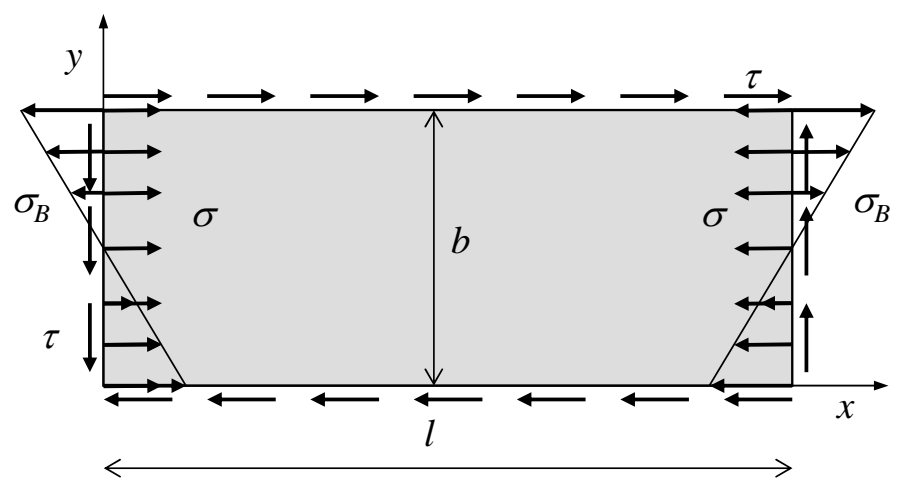

Fig. 1 Dimension of the rectangular plate and stresses 


$$
\begin{aligned}
& \hat{\sigma}_{c r}=k_{C} \sigma_{e} \\
& \sigma_{e}=\frac{\pi^{2} E}{12\left(1-\mu^{2}\right)}\left(\frac{t}{b}\right)^{2} \\
& k_{C}=4.00 \\
& \hat{\tau}_{c r}=k_{S} \sigma_{e}, k_{S}=5.34+4.00 \beta^{2} \\
& \beta=\frac{b}{l} \\
& \hat{\sigma}_{B C r}=k_{B} \sigma_{e}, k_{B}=23.9
\end{aligned}
$$

本論文では, 単一平板と箱形断面梁における座屈応力を区別するため, 平板の座屈応力には, 「^」を上に付け て表記する. 圧縮とせん断と曲げの応力が複合する場合の座屈応力関係式として以下の式が知られている.

$$
\begin{aligned}
& \frac{\hat{\sigma}_{c r}^{\prime}}{\hat{\sigma}_{c r}}+\left(\frac{\hat{\tau}_{c r}^{\prime}}{\hat{\tau}_{c r}}\right)^{2}=1 \\
& \left(\frac{\hat{\sigma}_{B c r}^{\prime}}{\hat{\sigma}_{B c r}}\right)^{2}+\left(\frac{\hat{\tau}_{c r}^{\prime}}{\hat{\tau}_{c r}}\right)^{2}=1 \\
& \frac{\hat{\sigma}_{c r}^{\prime}}{\hat{\sigma}_{c r}}+\left(\frac{\hat{\sigma}_{B c r}^{\prime}}{\hat{\sigma}_{B c r}}\right)^{2}+\left(\frac{\hat{\tau}_{c r}^{\prime}}{\hat{\tau}_{c r}}\right)^{2}=1
\end{aligned}
$$

ただし， $\hat{\sigma}_{c r}^{\prime}$ と $\hat{\tau}_{c r}^{\prime} ， \hat{\sigma}_{B c r}^{\prime}$ は，応力が複合した場合のそれぞれの座屈応力成分である. 式(7)は, Iguchi（1938） が求めた座屈応力の関係を回帰式として表したものである. 式(8)は, Chwalla（1936）が提示したものであり, 理 論解析結果と良く一致する回帰式として提案されたものである. 式(9)は, Johnson (1951) が求めた結果をZiemian （2010）らが示したものである.

\section{$2 \cdot 2$ 圧縮とせん断の座屈応力関係式の導出}

本節では, 複数の応力が作用する平板の座屈応力関係式をエネルギー法（林, 1966, 赤坂,吉田, 2000）に基づい て求める. 図 1 において, 座屈による面外変位を $w$ とすると, 四辺単純支持では面外変位 $w$ は以下の通りに書き 表すことができる.

$$
w=\sum_{m=1}^{\infty} \sum_{n=1}^{\infty} C_{m n} \sin \frac{m \pi x}{l} \sin \frac{n \pi y}{b}
$$

平板の歪みエネルギー $U$, 圧縮応力のする仕事 $W_{C}$, せん断応力の寸る仕事 $W_{S}$ は以下の式で求められる.

$$
U=\frac{D}{2} \int_{0}^{b} \int_{0}^{l}\left[\left(\frac{\partial^{2} w}{\partial x^{2}}+\frac{\partial^{2} w}{\partial y^{2}}\right)^{2}-2(1-\mu)\left\{\frac{\partial^{2} w}{\partial x^{2}} \frac{\partial^{2} w}{\partial y^{2}}-\left(\frac{\partial^{2} w}{\partial x \partial y}\right)^{2}\right\} d x d y\right.
$$




$$
\begin{aligned}
& W_{C}=\frac{t}{2} \int_{0}^{b} \int_{0}^{l} \sigma\left(\frac{\partial w}{\partial x}\right)^{2} d x d y \\
& W_{S}=-t \int_{0}^{b} \int_{0}^{l} \tau\left(\frac{\partial w}{\partial x} \frac{\partial w}{\partial y}\right) d x d y \\
& D=\frac{E t^{3}}{12\left(1-\mu^{2}\right)}
\end{aligned}
$$

これらの式より，

$$
\frac{\partial}{\partial C_{m n}}\left(U-W_{C}-W_{S}\right)=0
$$

を満たす二つの応力が, 圧縮とせん断が複合した場合の座屈応力である. 上式より, せん断応力単独の場合 と同様に $m+n$ が偶数の時のみ考えると（林, 1966）, 係数 $C_{m n}$ に関する以下の連立方程式が得られる.

$$
\frac{\pi^{4} D l b}{4} C_{m n}\left[\left(\frac{m}{l}\right)^{2}+\left(\frac{n}{b}\right)^{2}\right]^{2}-\frac{\hat{\sigma}_{c r}^{\prime} \pi^{2} b t}{4 l} m^{2} C_{m n}-8 m n \hat{\tau}^{\prime}{ }_{c r} t \sum_{i=1}^{\infty} \sum_{j=1}^{\infty} \frac{i j C_{i j}}{\left(i^{2}-m^{2}\right)\left(j^{2}-n^{2}\right)}=0
$$

ただし, 上式における総和は, $i$ に関しては $m+i$ が奇数のときのみ, $j$ に関しては $n+j$ が奇数のときのみである. 上式を行列表記すると, 以下の通りとなる.

$$
\left[\begin{array}{cccc}
\beta^{3}\left(1+\frac{1}{\beta^{2}}\right)^{2}-\frac{\beta \hat{\sigma}_{c r}^{\prime}}{\sigma_{e}} & -\frac{4}{9} \frac{32 \hat{\tau}_{c r}^{\prime}}{\pi^{2} \sigma_{e}} & 0 & \ldots \\
-\frac{4}{9} \frac{32 \hat{\tau}_{c r}^{\prime}}{\pi^{2} \sigma_{e}} & 16 \beta^{3}\left(1+\frac{1}{\beta^{2}}\right)^{2}-\frac{4 \beta \hat{\sigma}_{c r}^{\prime}}{\sigma_{e}} & \frac{4}{5} \frac{32 \hat{\tau}_{c r}^{\prime}}{\pi^{2} \sigma_{e}} & \ldots \\
0 & \frac{4}{5} \frac{32 \hat{\tau}_{c r}^{\prime}}{\pi^{2} \sigma_{e}} & \beta^{3}\left(1+\frac{9}{\beta^{2}}\right)^{2}-\frac{\beta \hat{\sigma}_{c r}^{\prime}}{\sigma_{e}} & \ldots \\
\vdots & \vdots & \vdots & \ddots
\end{array}\right]\left\{\begin{array}{c}
C_{11} \\
C_{22} \\
C_{13} \\
\vdots
\end{array}\right\}=\left\{\begin{array}{c}
0 \\
0 \\
0 \\
\vdots
\end{array}\right\}
$$

式の係数行列の特性方程式 $=0$ より, 座屈時の応力関係式が得られるが, 無限次数の式となる. そこで, 見通し をよくするために, 低次数の項 $\left(C_{11}, C_{22}\right)$ のみを考慮して特性方程式を求めると, 以下の通りとなる.

$$
\left[\beta^{3}\left(1+\frac{1}{\beta^{2}}\right)^{2}-\frac{\beta \hat{\sigma}_{c r}^{\prime}}{\sigma_{e}}\right]\left[16 \beta^{3}\left(1+\frac{1}{\beta^{2}}\right)^{2}-\frac{4 \beta \hat{\sigma}_{c r}^{\prime}}{\sigma_{e}}\right]-\left(-\frac{4}{9} \frac{32 \hat{\tau}_{c r}^{\prime}}{\pi^{2} \sigma_{e}}\right)^{2}=0
$$

上式を変形して以下の通りに書き表せる.

$$
\left[1-\frac{\hat{\sigma}_{c r}^{\prime}}{\beta^{2}\left(1+\frac{1}{\beta^{2}}\right)^{2} \sigma_{e}}\right]\left[1-\frac{\hat{\sigma}_{c r}^{\prime}}{4 \beta^{2}\left(1+\frac{1}{\beta^{2}}\right)^{2} \sigma_{e}}\right]-\left[\frac{\hat{\tau}_{c r}^{\prime}}{\frac{9 \pi^{2}}{32} \beta^{3}\left(1+\frac{1}{\beta^{2}}\right)^{2} \sigma_{e}}\right]^{2}=0
$$


上式が意味することは，無限次数で表される座屈時の面外変位を低次数の項のみで近似した場合に，各座屈応力 が,

$$
\begin{aligned}
& \tilde{\hat{\sigma}}_{c r}=\tilde{k}_{C} \sigma_{e}, \quad \tilde{k}_{C}=\beta^{2}\left(1+\frac{1}{\beta^{2}}\right)^{2} \\
& \tilde{\hat{\tau}}_{c r}=\tilde{k}_{S} \sigma_{e}, \quad \tilde{k}_{S}=\frac{9 \pi^{2}}{32} \beta^{3}\left(1+\frac{1}{\beta^{2}}\right)^{2}
\end{aligned}
$$

と求められ，かつせん断と圧縮の座屈応力関係式が,

$$
\left(1-\frac{\hat{\sigma}_{c r}^{\prime}}{\tilde{\hat{\sigma}}_{c r}}\right)\left(1-\frac{\hat{\sigma}_{c r}^{\prime}}{4 \tilde{\hat{\sigma}}_{c r}}\right)-\left(\frac{\hat{\tau}_{c r}^{\prime}}{\tilde{\hat{\tau}}_{c r}}\right)^{2}=0
$$

と求められることである，上式において，上付きの「 」は暫定的な近似值であることを表す.

ここで例えば, $\beta=1$ とすると, $\tilde{k}_{C}=4$ となり厳密解の $k_{C}$ (式(3)) と一致するが, $\tilde{k}_{S}=11.10$ となり, 林ら (1966) が指摘しているように， $k_{s}=9.34$ (式(4)）と比較してあまり精度が良くない. そこで本論文では, 誤差が大きい 上式の $\tilde{\hat{\sigma}}_{c r}, \tilde{\hat{\tau}}_{c r}$ の代わりに，厳密解および高精度な解である式(1)，(4)を利用して，以下の通りに書き表す.

$$
\left(1-\frac{\hat{\sigma}_{c r}^{\prime}}{\hat{\sigma}_{c r}}\right)\left(1-\frac{\hat{\sigma}_{c r}^{\prime}}{4 \hat{\sigma}_{c r}}\right)-\left(\frac{\hat{\tau}_{c r}^{\prime}}{\hat{\tau}_{c r}}\right)^{2}=0
$$

すなわち上式は, 圧縮とせん断が複合する場合に, 無限級数で表される座屈時の面外变形を低次数の項で近似し たのちエネルギー法に基づいて得られる 2 次形式の座屈応力関係式を示している. 結果として, 公知の式(7)とは 異なる式となった.

\section{$2 \cdot 3$ 曲げとせん断の座屈応力関係式の導出}

前節の考え方を踏襲して, 本節では, 図 1 の平板に対して純曲げ応力 $\sigma_{B}$ とせん断応力 $て$ ど作用する場合につ いて，その座屈応力関係式をエネルギー法に基づいて求める.

平板の歪みエネルギーは式(11), せん断による仕事は式(13)であり, 曲げによる仕事は以下の通りである.

$$
W_{B}=\frac{t}{2} \int_{0}^{b}\left[\sigma_{B}\left(1-\frac{2}{b} y\right) \int_{0}^{l}\left(\frac{\partial w}{\partial x}\right)^{2} d x\right] d y
$$

前節と同様にして，エネルギー法に則り，係数 $C_{m n}$ に関する連立方程式を求める.

$$
\begin{aligned}
& \frac{\partial}{\partial C_{m n}}\left(U-W_{S}-W_{B}\right)=0 \\
& \frac{\pi^{2} l b^{3}}{32} \frac{\pi^{2} D}{b^{2} t} C_{m n}\left[\left(\frac{m}{l}\right)^{2}+\left(\frac{n}{b}\right)^{2}\right]^{2}-m n \hat{\tau}^{\prime}{ }_{c r}^{\prime} \sum_{i=1}^{\infty} \sum_{j=1}^{\infty} \frac{i j C_{i j}}{\left(i^{2}-m^{2}\right)\left(j^{2}-n^{2}\right)}-\frac{1}{2} b l \hat{\sigma}_{B c r}^{\prime}\left(\frac{m}{l}\right)^{2} \sum_{i=1}^{\infty} \frac{n j C_{m j}}{\left(j^{2}-n^{2}\right)^{2}}=0
\end{aligned}
$$




$$
\left[\begin{array}{cccc}
\frac{\pi^{2} \beta^{3} \sigma_{e}}{32}\left(1+\frac{1}{\beta^{2}}\right)^{2} & -\frac{\beta \hat{\sigma}_{B c r}^{\prime}}{9} & 0 & \ldots \\
-\frac{\beta \hat{\sigma}_{B c r}^{\prime}}{9} & \frac{\pi^{2} \beta^{3} \sigma_{e}}{32}\left(1+\frac{4}{\beta^{2}}\right)^{2} & \frac{4 \hat{\tau}_{c r}^{\prime}}{9} & \ldots \\
0 & \frac{4 \hat{\tau}_{c r}^{\prime}}{9} & \frac{\pi^{2} \beta^{3} \sigma_{e}}{32}\left(4+\frac{1}{\beta^{2}}\right)^{2} & \ldots \\
\vdots & \vdots & \vdots & \ddots
\end{array}\right]\left\{\begin{array}{c}
C_{11} \\
C_{12} \\
C_{21} \\
\vdots
\end{array}\right\}=\left\{\begin{array}{c}
0 \\
0 \\
0 \\
\vdots
\end{array}\right\}
$$

さらに，低次数の項（ $\left.C_{11}, C_{12}, C_{21}\right)$ のみを考慮して特性方程式を求めると，以下の通りとなる.

$$
\begin{aligned}
& \left(\frac{\pi^{2} \beta^{3} \sigma_{e}}{32}\right)^{2}\left(1+\frac{1}{\beta^{2}}\right)^{2}\left(1+\frac{4}{\beta^{2}}\right)^{2}\left(4+\frac{1}{\beta^{2}}\right)^{2}-\left(4+\frac{1}{\beta^{2}}\right)\left(-\frac{\beta \hat{\sigma}_{B c r}^{\prime}}{9}\right)^{2}-\left(1+\frac{1}{\beta^{2}}\right)^{2}\left(\frac{4 \hat{\tau}_{c r}^{\prime}}{9}\right)^{2}=0 \\
& {\left[\frac{\hat{\sigma}_{B c r}^{\prime}}{\frac{9 \pi^{2} \beta^{2}}{32}\left(1+\frac{1}{\beta^{2}}\right)\left(1+\frac{4}{\beta^{2}}\right) \sigma_{e}}\right]^{2}+\left[\frac{\hat{\tau}_{c r}^{\prime}}{\frac{9 \pi^{2} \beta^{3}}{128}\left(1+\frac{4}{\beta^{2}}\right)\left(4+\frac{1}{\beta^{2}}\right) \sigma_{e}}\right]^{2}=1} \\
& \tilde{\hat{\sigma}}_{B c r}=\tilde{k}_{B} \sigma_{e}, \quad \tilde{k}_{B}=\frac{9 \pi^{2} \beta^{2}}{32}\left(1+\frac{1}{\beta^{2}}\right)\left(1+\frac{4}{\beta^{2}}\right) \\
& \tilde{\hat{\tau}}_{c r}=\tilde{k}_{s} \sigma_{e}, \quad \tilde{k}_{s}=\frac{9 \pi^{2} \beta^{3}}{128}\left(1+\frac{4}{\beta^{2}}\right)\left(4+\frac{1}{\beta^{2}}\right)
\end{aligned}
$$

前節と同様に, $\beta=1$ とすると, $\tilde{k}_{B}=27.76, \quad \tilde{k}_{S}=17.35$ となり, $k_{B}=23.9, \quad k_{S}=9.34$ に比べて精度が良くな い. $\tilde{\hat{\sigma}}_{B c r}$ を式(6)に，また $\tilde{\hat{\tau}}_{c r}$ を式(4)に置き換えることにより，曲げとせん断が複合する場合の座屈応力関係 式(8)が求められる.

\section{$2 \cdot 4$ 圧縮と曲げの座屈応力関係式の導出}

$2 \cdot 2$ 節と同様にして, 本節では, 図 1 の平板に対して圧縮応力 $\sigma$ と純曲げ応力 $\sigma_{B}$ とが作用する場合の座屈応力 関係式をエネルギー法に基づいて求める.

平板の歪みエネルギーは式(11), 圧縮による仕事は式(12)であり, 曲げによる仕事は式(24)である. ただし本節で は, $x$ 軸方向の変位形に関して単一の正弦波で表すことができるため（林, 1966), 面外変位形 $w$ を以下の通りと する.

$$
w=\sin \frac{m \pi x}{l} \sum_{n=1}^{\infty} C_{n} \sin \frac{n \pi y}{b}
$$

以下，同様にして，係数 $C_{n}$ に関する連立方程式を求める.

$$
\begin{aligned}
& \frac{\partial}{\partial C_{n}}\left(U-W_{C}-W_{B}\right)=0 \\
& \frac{\pi^{2}}{4} \beta^{2}\left(m^{2}+\frac{n^{2}}{\beta^{2}}\right)^{2} \sigma_{e} C_{n}-\frac{\pi^{2}}{4} m^{2} \hat{\sigma}_{c r}^{\prime} C_{n}-4 \hat{\sigma}_{B c r}^{\prime} m^{2} n \sum_{j=1}^{\infty} \frac{j}{\left(j^{2}-n^{2}\right)^{2}} C_{j}=0
\end{aligned}
$$




$$
\left[\begin{array}{cc}
\frac{\pi^{2}}{4}\left[\beta^{2} \sigma_{e}\left(m^{2}+\frac{1}{\beta^{2}}\right)^{2}-m^{2} \hat{\sigma}_{c r}^{\prime}\right] & -\frac{8 m^{2}}{9} \hat{\sigma}_{B c r}^{\prime} \\
-\frac{8 m^{2}}{9} \hat{\sigma}_{B c r}^{\prime} & \frac{\pi^{2}}{4}\left[\beta^{2}\left(m^{2}+\frac{4}{\beta^{2}}\right)^{2} \sigma_{e}-m^{2} \hat{\sigma}_{c r}^{\prime}\right] \\
\vdots & \cdots \\
\vdots & \ddots
\end{array}\right]\left\{\begin{array}{c}
C_{1} \\
C_{2} \\
\vdots
\end{array}\right\}=\left\{\begin{array}{c}
0 \\
0 \\
\vdots
\end{array}\right\}
$$

低次数の項 $\left(C_{1}, C_{2}\right)$ のみを考慮して特性方程式を求めると，以下の通りとなる.

$$
\begin{aligned}
& \frac{\pi^{2}}{4}\left[\beta^{2} \sigma_{e}\left(m^{2}+\frac{1}{\beta^{2}}\right)^{2}-m^{2} \hat{\sigma}_{c r}^{\prime}\right] \frac{\pi^{2}}{4}\left[\beta^{2}\left(m^{2}+\frac{4}{\beta^{2}}\right)^{2} \sigma_{e}-m^{2} \hat{\sigma}_{c r}^{\prime}\right]-\left(-\frac{8 m^{2}}{9} \hat{\sigma}_{B c r}^{\prime}\right)^{2}=0 \\
& {\left[1-\frac{\sigma_{c r}^{\prime}}{\frac{\beta^{2}}{m^{2}}\left(m^{2}+\frac{1}{\beta^{2}}\right)^{2} \sigma_{e}}\right]\left[1-\frac{\sigma_{c r}^{\prime}}{\frac{\beta^{2}}{m^{2}}\left(m^{2}+\frac{4}{\beta^{2}}\right)^{2} \sigma_{e}}\right]-\frac{\sigma_{B c r}^{\prime 2}}{\left[\left(\frac{9 \pi^{2} \beta^{2}}{32 m^{2}}\right)\left(m^{2}+\frac{1}{\beta^{2}}\right)\left(m^{2}+\frac{4}{\beta^{2}}\right) \sigma_{e}\right]^{2}}=0} \\
& \tilde{\hat{\sigma}}_{B c r}=\tilde{k}_{B} \sigma_{e}, \quad \tilde{k}_{B}=\frac{9 \pi^{2} \beta^{2}}{32 m^{2}}\left(m^{2}+\frac{1}{\beta^{2}}\right)\left(m^{2}+\frac{4}{\beta^{2}}\right) \\
& \tilde{\hat{\sigma}}_{c r 1}=\frac{\beta^{2}}{m^{2}}\left(m^{2}+\frac{1}{\beta^{2}}\right)^{2} \sigma_{e}, \quad \tilde{\hat{\sigma}}_{c r 2}=\frac{\beta^{2}}{m^{2}}\left(m^{2}+\frac{4}{\beta^{2}}\right)^{2} \sigma_{e}
\end{aligned}
$$

$m$ は座屈応力が最小となるように決まるから, 式(38)は $m \beta=2$ として $\tilde{k}_{B}=24.98$ が得られるが, 厳密解 $k_{B}=23.9$ に対して若干精度が悪い. また，式(39)のうち前者は， $m \beta=1$ とすると，

$$
\tilde{\hat{\sigma}}_{c r 1}=\frac{\beta^{2}}{m^{2}}\left(m^{2}+\frac{1}{\beta^{2}}\right)^{2} \sigma_{e}=4 \sigma_{e}=\hat{\sigma}_{c r}
$$

となり，厳密解と一致する，後者は， $m \beta=2$ とすると，

$$
\tilde{\hat{\sigma}}_{c r 2}=\frac{\beta^{2}}{m^{2}}\left(m^{2}+\frac{4}{\beta^{2}}\right)^{2} \sigma_{e}=16 \sigma_{e}=4 \hat{\sigma}_{c r}
$$

となる，以上より，圧縮と曲げの応力が作用寸る平板において，以下の座屈応力関係式が得られる.

$$
\left(1-\frac{\hat{\sigma}_{c r}^{\prime}}{\hat{\sigma}_{c r}}\right)\left(1-\frac{\hat{\sigma}_{c r}^{\prime}}{4 \hat{\sigma}_{c r}}\right)-\left(\frac{\hat{\sigma}_{B c r}^{\prime}}{\hat{\sigma}_{B c r}}\right)^{2}=0
$$

なお，本節までで求めた関係式は，周辺単純支持の条件で面外変位形を規定しているが，結果として得られた関 係式は，その他の境界条件においても成立すると考えられる，なぜなら，関係式は，最終的には座屈応力成分と 単独応力が作用寸る場合の座屈応力との比で表されており, この単独の座屈応力として, 他の境界条件で求めら れる座屈応力を用いることができるからである. 


\section{$2 \cdot 5$ 座屈応力関係式の類似性}

前節までに, 圧縮とせん断, および曲げのうち二つの応力が作用寸るいくつかの平板の座屈応力関係式を示し た．本節では，これらの式の類似性を示す．表記を明解にするために

$X=\frac{\hat{\sigma}_{c r}^{\prime}}{\hat{\sigma}_{c r}}$ or $\frac{\hat{\sigma}_{B c r}^{\prime}}{\hat{\sigma}_{B c r}}, \quad y=\frac{\hat{\tau}_{c r}^{\prime}}{\hat{\tau}_{c r}}$ or $\frac{\hat{\sigma}_{B c r}^{\prime}}{\hat{\sigma}_{B c r}}$

とおく，すると，二つの応力が複合する場合の式(7)，(8)，(23)，(42)は以下のように書くことができる.

$$
\begin{aligned}
& x+y^{2}=1 \\
& (1-x)\left(1-\frac{1}{4} x\right)-y^{2}=0 \\
& x^{2}+y^{2}=1
\end{aligned}
$$

これら三つの式を俯瞰して

$$
(1-x)(1-c x)-y^{2}=0
$$

なる式を考えたとき，式(43)，(44)，(45)は，式(46)で $c=0, c=1 / 4 ， c=-1$ に対応する． $c$ を変化させたときの式(46) のグラフの変化を図 2 に示す. 寸なわち式(46)は, 一つのパラメーターを導入することにより, 様々な複合荷重 時の座屈応力関係式を総括して表すことができることを示している.

$c=1 / 4$ および $c=-1$ に相当する式は, エネルギー法により得られた座屈固有方程式を基礎として求めているが, 式(7)は理論解析により得られた座屈応力関係を回帰式として表したものであるため, $c=0$ の場合の物理的な意味 は明確ではない. しかし, 構造や応力の種類によって適切な $c$ が存在すると仮定すれば, $c=0$ とすることも意味 があり, $c$ の值を選択することにより, 理論解析や FEM 計算の結果に充分に対応する座屈応力関係式が得られる と考えることができる.

なお，三つの応力が複合する場合については，今後の検討課題とする.

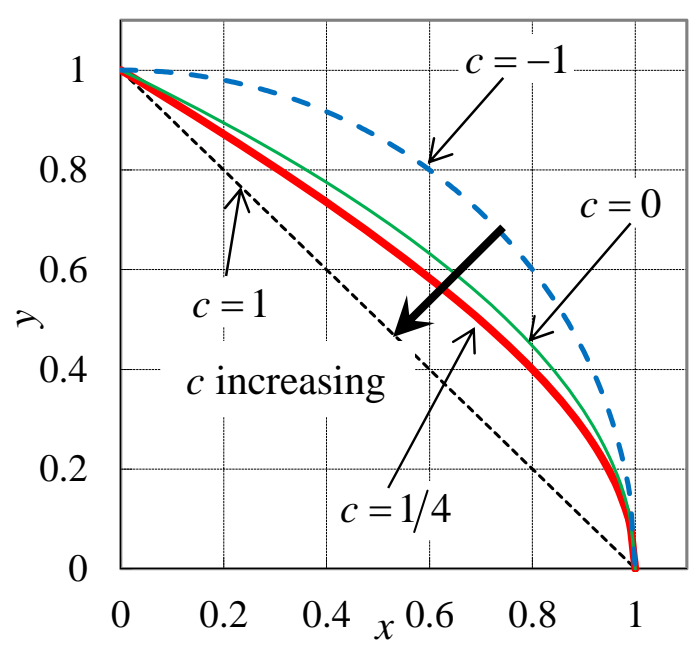

Fig. 2 Variation of buckling stress relation equations with parameter $c$ 


\section{3. 箱形断面梁の軸圧縮時の圧縮座屈応力}

\section{$3 \cdot 1$ 箱形断面梁に対する従来の圧縮座屈応力の考え方}

本章では, 図 3 に示すような幅 $b$ (横板), 高さ $h$ (縦板) (ただし, $b \geq h$ の場合のみを考慮), 長さ $l$, 板厚 $t$ の薄板で構成された箱形断面の梁を対象に考える. この梁の一端に, 圧縮荷重 $P$ が作用するとき, 材料のヤ ング率を $E$, ポアソン比を $\mu$ とすると, 箱形断面梁を構成する平板に生じる圧縮応力は以下の通りとなる.

$$
P=2(b+h) t \sigma
$$

この圧縮応力によって箱形断面梁に座屈が発生する. 単純に 4 枚の薄板を単独の長方形平板と考えた場合, 幅の大きい横板で座屈が発生し，その圧縮座屈応力 $\sigma_{c r}$ は，平板の座屈応力の式(1)と同じとなる (AISI/CARS 2002, 2002, CARS manual, 2002). しかし, 横板に圧縮座屈が発生し面外変形を生じた場合, それに起因して, 縦板にも面外変形を生じる. 式(1)は図 1 における横板のみの座屈を表すに過ぎず, 縦板の影響が考慮されて いない. 実際に FEM によりこのような梁の圧縮座屈応力を求めてみると, 縦板の幅によりその值が変化する ことが確認できる（5 章の図 6 参照)。したがって，式(1)のみで圧縮座屈応力を判断することは誤差を含む可 能性がある。

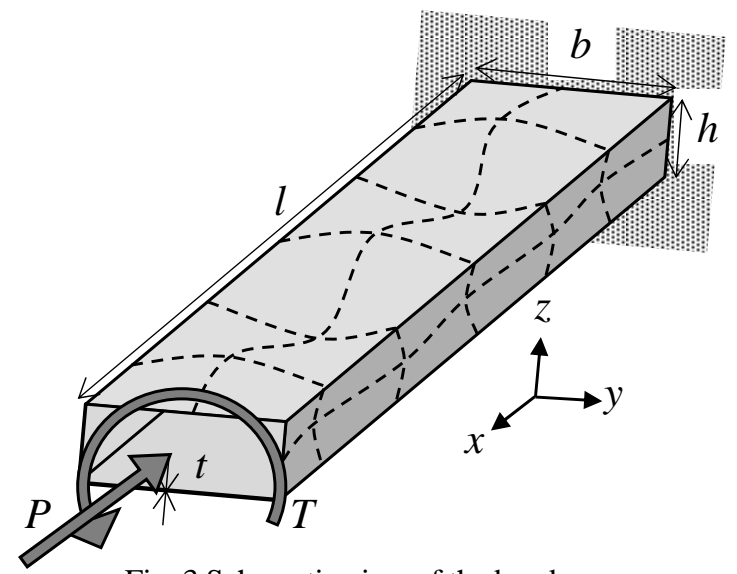

Fig. 3 Schematic view of the box beam

\section{$3 \cdot 2$ ねじり座屈からの推定}

箱形断面梁の軸方向圧縮座屈に対しても,幅 $b$ の横板だけでなく幅 $h$ の縦板の影響を考慮する必要がある. 端部を単純支持とした箱形断面梁のねじり座屈時のせん断応力に関しては，前の論文（古巣他，2013a， 2013b）で以下の通りに求めている.

$$
\begin{aligned}
& \tau_{c r}=g_{S} \sigma_{g} \\
& g_{S}=4.00+5.34 \frac{\frac{b}{l}+\frac{h}{l}}{\left(\frac{b}{l}\right)^{3}+\left(\frac{h}{l}\right)^{3}} \\
& \sigma_{g}=\frac{\pi^{2} E}{12\left(1-\mu^{2}\right)}\left(\frac{t}{l}\right)^{2}
\end{aligned}
$$

圧縮の座屈応力に関して前の論文と同様な手順で考えると, まず平板の圧縮座屈応力を $\tilde{\sigma}_{c r}$ とて, 


$$
\begin{aligned}
& \tilde{\sigma}_{c r}=k_{C} \frac{\pi^{2} E}{12\left(1-\mu^{2}\right)}\left(\frac{t}{b}\right)^{2}=k_{C}\left(\frac{l}{b}\right)^{2} \frac{\pi^{2} E}{12\left(1-\mu^{2}\right)}\left(\frac{t}{l}\right)^{2}=\tilde{g}_{C} \sigma_{g} \\
& \tilde{g}_{C}=k_{C}\left(\frac{l}{b}\right)^{2}=4.00\left(\frac{l}{b}\right)^{2}
\end{aligned}
$$

と書き表すことができる． $\sigma_{g}$ は $b$ に影響されない数であり， $\tilde{g}_{C}$ のみが $b$ に影響される数となる．前節で述べた ように圧縮座屈応力は $b$ と $h$ の両方の影響を受けることから，叔じり座屈と同様に，この式中の $(l / b)^{2}$ の代わりに $l / b$ と $l / h$ に関して対称となるような式を適用寸れば近似解が得られることが推定できる．㸚じり座屈と同様に考 えると，以下の形の修正座屈係数を仮定できる.

$$
g_{C}=4.00 \frac{\frac{b}{l}+\frac{h}{l}}{\left(\frac{b}{l}\right)^{3}+\left(\frac{h}{l}\right)^{3}}
$$

これより，箱形断面梁の圧縮座屈応力 $\sigma_{c r}$ は以下の通りに書き表される.

$$
\sigma_{c r}=g_{C} \sigma_{g}
$$

\section{$3 \cdot 3$ 圧縮座屈応カのエネルギ一法による導出}

本節では前の論文（古巣他, 2013a） と同様な仮定をしてエネルギー法により求める．横板の面外（ $\mathrm{z}$ 軸方向） 変位を $w$, 縦板の面外 $(y$ 軸方向) 変位を $v$ とし, 縦板, 横板とも四辺単純支持平板とすると, 座屈時の面外変 位を以下の通りに書き表すことができる.

$$
w=B \sin \frac{m \pi x}{l} \sin \frac{n \pi y}{b}, \quad v=H \sin \frac{m \pi x}{l} \sin \frac{n \pi z}{h}
$$

各板が接する辺における互いの角度が変形後も直角を保つと仮定すると，その傾きは

$$
\left.\frac{\partial w}{\partial y}\right|_{y=0}=\frac{n \pi}{b} B \sin \frac{m \pi x}{l},\left.\quad \frac{\partial v}{\partial z}\right|_{z=0}=\frac{n \pi}{h} H \sin \frac{m \pi x}{l}
$$

であり，これらの関係よりそれぞれの係数 $B, H$ は，共用の係数

$$
\frac{B}{b}=\frac{H}{h}=\frac{\Phi}{\sqrt{b h}}
$$

この関係式より $, w, v$ は以下の通りに置き直すことができる.

$$
w=\sqrt{\frac{b}{h}} \Phi \sin \frac{m \pi x}{l} \sin \frac{n \pi y}{b}, v=\sqrt{\frac{h}{b}} \Phi \sin \frac{m \pi x}{l} \sin \frac{n \pi z}{h}
$$

板の曲げ歪みエネルギー $U$ と圧縮荷重による仕事 $W_{C}$ から, 箱形断面梁の 4 枚の板の $U$ と $W_{C}$ は $w$ とを用いて 以下の式で求められる. 


$$
\begin{gathered}
U=2 \times \frac{D}{2} \int_{0}^{b} \int_{0}^{l}\left\{\left(\frac{\partial^{2} w}{\partial x^{2}}+\frac{\partial^{2} w}{\partial y^{2}}\right)-2(1-\mu)\left[\frac{\partial^{2} w}{\partial x^{2}} \frac{\partial^{2} w}{\partial y^{2}}-\left(\frac{\partial^{2} w}{\partial x \partial y}\right)^{2}\right]\right\} d x d y \\
+2 \times \frac{D}{2} \int_{0}^{h} \int_{0}^{l}\left\{\left(\frac{\partial^{2} v}{\partial x^{2}}+\frac{\partial^{2} v}{\partial z^{2}}\right)-2(1-\mu)\left[\frac{\partial^{2} v}{\partial x^{2}} \frac{\partial^{2} v}{\partial z^{2}}-\left(\frac{\partial^{2} v}{\partial x \partial z}\right)^{2}\right]\right\} d x d z \\
W_{C}=2 \times \frac{t}{2} \int_{0}^{b} \int_{0}^{l} \sigma\left(\frac{\partial w}{\partial x}\right)^{2} d x d y+2 \times \frac{t}{2} \int_{0}^{h} \int_{0}^{l} \sigma\left(\frac{\partial v}{\partial x}\right)^{2} d x d z
\end{gathered}
$$

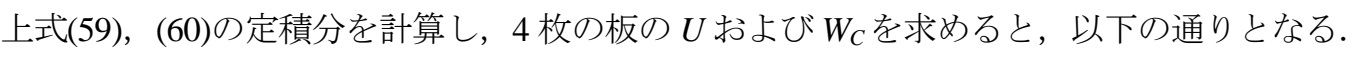

$$
\begin{aligned}
& U=\frac{\pi^{4} D l}{4}\left\{\frac{b^{2}}{h}\left[\left(\frac{m}{l}\right)^{2}+\left(\frac{n}{b}\right)^{2}\right]^{2}+\frac{h^{2}}{b}\left[\left(\frac{m}{l}\right)^{2}+\left(\frac{n}{h}\right)^{2}\right]^{2}\right\} \Phi^{2} \\
& W_{C}=\sigma t \frac{\pi^{2}}{4}\left(\frac{l}{b} \frac{l}{h}\right)\left[\left(\frac{b}{l}\right)^{3}+\left(\frac{h}{l}\right)^{3}\right] m^{2} \Phi^{2}
\end{aligned}
$$

ただし，。は式(47)から求められる圧縮応力であり $D$ は板の曲げ剛性で以下の通りである.

$$
D=\frac{E t^{3}}{12\left(1-\mu^{2}\right)}
$$

これらの式より, 以下の式を満たす $\sigma か ゙$ 縮座屈応力 $\sigma_{c r}$ である.

$$
\begin{aligned}
& \frac{\partial}{\partial \Phi}\left(U-W_{C}\right)=0 \\
& \frac{\partial U}{\partial \Phi}=\frac{\pi^{4} D l}{2}\left\{\frac{b^{2}}{h}\left[\left(\frac{m}{l}\right)^{2}+\left(\frac{n}{b}\right)^{2}\right]^{2}+\frac{h^{2}}{b}\left[\left(\frac{m}{l}\right)^{2}+\left(\frac{n}{h}\right)^{2}\right]^{2}\right\} \Phi \\
& \frac{\partial W_{C}}{\partial \Phi}=\sigma_{c r} t \frac{\pi^{2}}{2}\left(\frac{l}{b} \frac{l}{h}\right)\left[\left(\frac{b}{l}\right)^{3}+\left(\frac{h}{l}\right)^{3}\right] m^{2} \Phi
\end{aligned}
$$

より，式(64)を計算すると以下の通りとなる.

$$
\frac{\pi^{4} D l}{2}\left\{\frac{b^{2}}{h}\left[\left(\frac{m}{l}\right)^{2}+\left(\frac{n}{b}\right)^{2}\right]^{2}+\frac{h^{2}}{b}\left[\left(\frac{m}{l}\right)^{2}+\left(\frac{n}{h}\right)^{2}\right]^{2}\right\} \Phi-\sigma_{c r} t \frac{\pi^{2}}{2}\left(\frac{l}{b} \frac{l}{h}\right)\left[\left(\frac{b}{l}\right)^{3}+\left(\frac{h}{l}\right)^{3}\right] m^{2} \Phi=0
$$

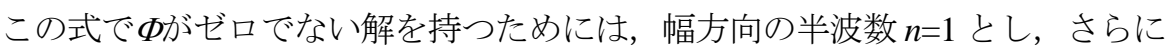

$$
\sigma_{g}=\frac{\pi^{2} E}{12\left(1-\mu^{2}\right)}\left(\frac{t}{l}\right)^{2}
$$


とすると， $\sigma_{c r}$ が以下の式を満たす必要がある.

$$
\begin{aligned}
& \sigma_{g}\left\{\frac{l}{h}\left(\frac{b}{l}\right)^{2}\left[m^{2}+\left(\frac{l}{b}\right)^{2}\right]^{2}+\frac{l}{b}\left(\frac{h}{l}\right)^{2}\left[m^{2}+\left(\frac{l}{h}\right)^{2}\right]^{2}\right\}-\sigma_{c r}\left(\frac{l}{b} \frac{l}{h}\right)\left[\left(\frac{b}{l}\right)^{3}+\left(\frac{h}{l}\right)^{3}\right] m^{2}=0 \\
& \sigma_{c r}=\frac{\left(\frac{b}{l}\right)^{3}\left[m^{2}+\left(\frac{l}{b}\right)^{2}\right]^{2}+\left(\frac{h}{l}\right)^{3}\left[m^{2}+\left(\frac{l}{h}\right)^{2}\right]^{2}}{m^{2}\left[\left(\frac{b}{l}\right)^{3}+\left(\frac{h}{l}\right)^{3}\right]} \sigma_{g}=g_{C} \sigma_{g}
\end{aligned}
$$

上式で, $m$ は $g_{C}$ が最小となるように決まるため, $g_{C}$ の $m$ に関する最小值は以下の通りとなる.

$$
g_{C}=\frac{2\left(\frac{b}{l}+\frac{h}{l}\right)\left[\sqrt{\frac{b^{2}-b h+h^{2}}{b h}}+1\right]}{\left(\frac{b}{l}\right)^{3}+\left(\frac{h}{l}\right)^{3}}
$$

上式は, $h=b$ であるとき, 式(53)と同じ式となる. 本論文では, 式(53)と式(71)に関して, FEM 計算結果と比較し て精度を検証し，圧縮座屈応力の座屈係数の式を決定する.

\section{4. 箱形断面梁の圧縮ねじり座屈}

本章では, 図 3 に示すような軸圧縮荷重 $P$ と㸚じりトルク $T$ が作用寸る場合の箱形断面梁の座屈応力関係式を 求める.長方形平板のせん断と圧縮の応力が作用する場合の座屈応力関係式は, 一般に以下の式が知られている.

$$
\frac{\hat{\sigma}_{c r}^{\prime}}{\hat{\sigma}_{c r}}+\left(\frac{\hat{\tau}_{c r}^{\prime}}{\hat{\tau}_{c r}}\right)^{2}=1
$$

なお， 2 章と同様に，上付きの「^」は平板における座屈応力を示寸．筆者らも前の報告（古巣他, 2012b）にお いて以下の式を提案し，上式より悠密解に近い関係が得られることを確認している.

$$
\left(1-\frac{\hat{\sigma}_{c r}^{\prime}}{\hat{\sigma}_{c r}}\right)\left(1-\frac{\hat{\sigma}_{c r}^{\prime}}{4 \hat{\sigma}_{c r}}\right)-\left(\frac{\hat{\tau}_{c r}^{\prime}}{\hat{\tau}_{c r}}\right)^{2}=0
$$

ここで， $\hat{\sigma}_{c r}$ は平板の圧縮座屈応力， $\hat{\tau}_{c r}$ はせん断座屈応力であり， $\hat{\sigma}_{c r}^{\prime}$ と $\hat{\tau}_{c r}^{\prime}$ は, 圧縮とせん断が複合した場合 のそれぞれの座屈応力成分である.

圧縮力 $P$ とねじりトルク $T$ が作用寸る箱形断面梁において, 前の論文（古巣他, 2013a）および 3 ・ 3 節と同様 にエネルギー法により座屈応力関係式を求めることが可能であるが，厳密な関係式を得るには無限の項を必要と 寸るため, 簡便に取り扱うことができない. しかし，断面を構成する 4 枚の板には圧縮とせん断の応力が作用す るため, 平板と同様な関係があることが期待できる. そこで本論文では， $\sigma_{c r}$ は式(54)で表される箱形断面梁の圧 縮座屈応力， $\tau_{c r}$ は式(48)で表されるせん断座屈応力であり， $\sigma_{c r}^{\prime}$ と $\tau_{c r}^{\prime}$ は，圧縮とせん断が複合した場合のそれ ぞれの座屈応力成分として, 以下の 2 つ式を箱形断面梁の座屈応力関係式として提案し, FEM 計算結果と比較 して精度を検証する。 


$$
\begin{aligned}
& \left(1-\frac{\sigma_{c r}^{\prime}}{\sigma_{c r}}\right)\left(1-\frac{\sigma_{c r}^{\prime}}{4 \sigma_{c r}}\right)-\left(\frac{\tau_{c r}^{\prime}}{\tau_{c r}}\right)^{2}=0 \\
& \frac{\sigma_{c r}^{\prime}}{\sigma_{c r}}+\left(\frac{\tau_{c r}^{\prime}}{\tau_{c r}}\right)^{2}=1
\end{aligned}
$$

\section{5. 検証計算}

\section{$5 \cdot 1$ 圧縮座屈応力係数の精度検証}

本節では, 3 章で示した圧縮座屈応力の二つの修正座屈係数の精度を, FEMによる計算との比較により検証す る. 幅 $b$, 高さ $h$, 長さ $l$, 板厚 $t$ に対して, 表 1 に示寸ような 47 種の諸元で座屈固有值解析を実施した. ヤング 率 $E=205.8 \mathrm{GPa}$ ，ポアソン比 $\mu=0.3$ とした. FEM ソルバーとして ANSYS を用い，図 4 にその FEMメッシュの概 況を示す. 4 節点シェル要素（SHELL181）を用い, 要素の大きさはすべての諸元で縦横とも $2.5 \mathrm{~mm}$ とした. 圧 縮力の作用点を片端部の断面の中心点とし，その中心点と端面上の全節点を関係づけ，端面に均一に圧縮荷重が 作用するように設定した．対端は端面上の全節点の並進自由度を拘束している．シェル要素数および荷重点を除 く節点数は, 最も少ない諸元 $(l=300 \mathrm{~mm}, b=80, h=30, t=0.8$ および 1.0$)$ のモデルでそれぞれ 10560 および 10648 であり，最も多い諸元 $(l=500 \mathrm{~mm}, \quad b=120, h=120, t=1.2)$ でそれぞれ 38400 および 38592 である.

図 5 に $, l=400, b=100, h=30 \sim 100, t=1.0 \mathrm{~mm}$ のときの, 座屈モードの FEM 計算結果の一例を示す. 同じ諸元 の座屈圧縮応力に関して, 横軸を断面のアスペクト比 $(h / b)$ として, FEM, 平板理論（Plate Theory）から得られ る結果を図 6 に重ねて示寸.

FEM 計算により得られた圧縮座屈応力に対寸る式(53)および式(71)で求められる応力の誤差を図 7 に示す.た だし，誤差は， $\sigma_{\text {crFEM }}$ を FEM から求めた圧縮座屈応力とし， $\sigma_{\text {crCurrent }}$ を式(53)または式(71)から求められる圧縮座 屈応力として, 以下の式により求めている.

$$
\text { Error[\%] }=\frac{\sigma_{c r C u r r e n t}-\sigma_{c r F E M}}{\sigma_{c r F E M}} \times 100
$$

図 6 から, 幅 $b$ が一定であっても FEM で求めた圧縮座屈応力は高さ $h$ により変化し, 平板理論の結果と異な ることがわかる. それに対し, 式(53)から求められる結果は, FEMの結果と充分に対応することがわかる.

図 7 に示寸ように, 単純にエネルギー法から求めた式(71)の結果は, アスペクト比 $h / b=1$ においては FEM 結果 との差は小さいが， $h / b$ が小さくなるにつれて誤差が大きくなっている. この理由は, アスペクト比が小さくな ると, 縦板が座屈するという仮定を満たさないためと考えられる. 寸なわち, 本論文では「横板が座屈するとき, 同時に縦板も座屈寸る」という考え方に基づいて定式化し, 得られた式から近似式を導出している. しかし, 図 5 からもわかるように, アスペクト比が小さくなるにつれて縦板が座屈を起こさず, 横板の幅 $b$ と縦板の幅 $h$ と

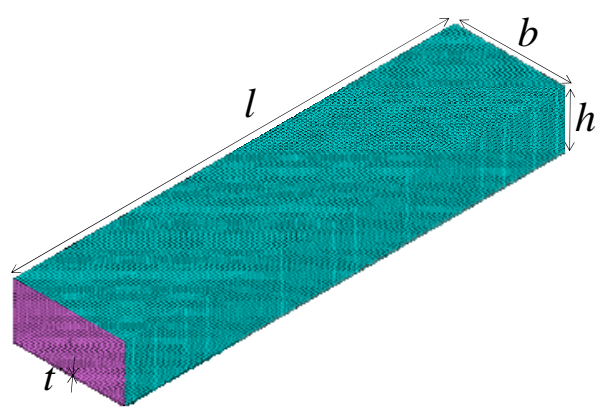

Fig. 4 Outline of finite element model of box beam 
が対称的に影響寸るという仮定が成り立たなくなることが要因と考えられる.

式(53)から得られる結果は，アスペクト比がおよそ 0.3 以上であれば，FEMによる結果との誤差がおよそ $6 \% 以$ 内であることがわかる. 自動車車体において本研究の対象と考える骨格部材においては, 0.4 以上のアスペクト比 を持つ形状が主流であるため, 式(53)から実用的な圧縮座屈応力を簡便に求められることがわかる.

Table 1 Dimension of finite element model of box beam [mm]

\begin{tabular}{|r|r|r|r|}
\hline Length $(l)$ & Width $(b)$ & Thickness $(t)$ & Height $(h)$ \\
\hline \multirow{3}{*}{300} & 80 & 0.8 & $30,40,50,60,70,80$ \\
\cline { 2 - 4 } & 80 & 1.0 & $30,40,50,60,70,80$ \\
\cline { 2 - 4 } & 90 & 1.0 & $30,40,50,60,70,80,90$ \\
\hline \multirow{3}{*}{400} & 80 & 1.0 & $25,30,40,50,60,70,80$ \\
\cline { 2 - 4 } & 90 & 1.0 & $30,40,50,60,70,80,90$ \\
\cline { 2 - 4 } & 100 & 1.0 & $30,40,50,60,70,80,90,100$ \\
\hline 500 & 120 & 1.2 & $40,60,80,100,110,120$ \\
\hline
\end{tabular}

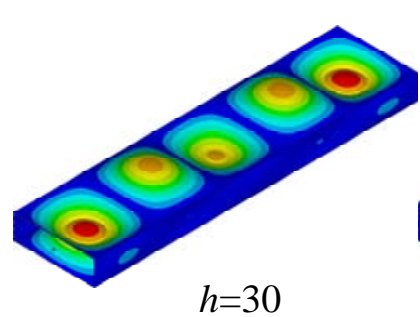

$h=30$

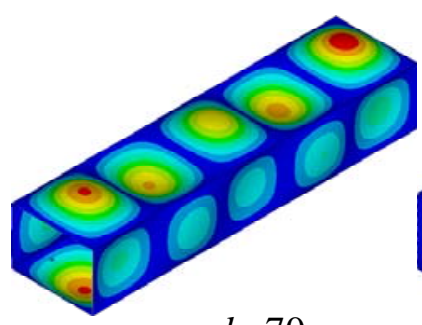

$h=70$

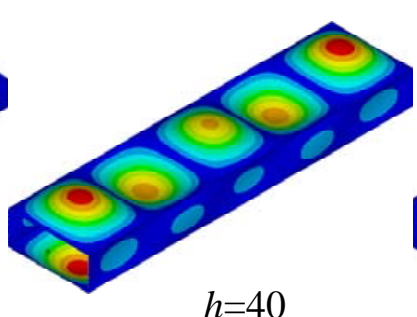

$h=40$

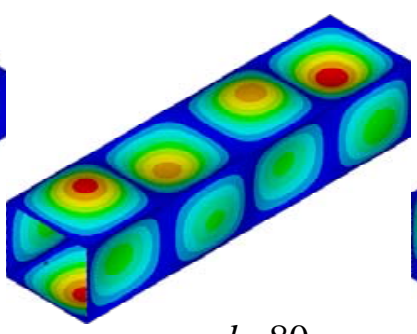

$h=80$

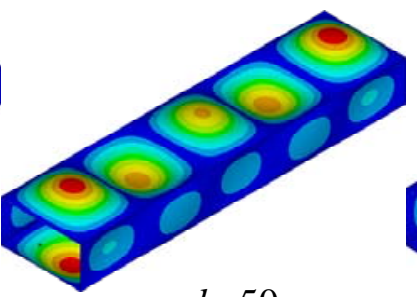

$h=50$

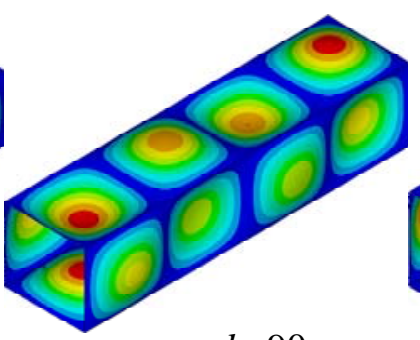

$h=90$

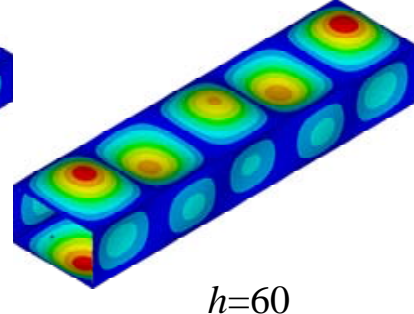

$h=60$

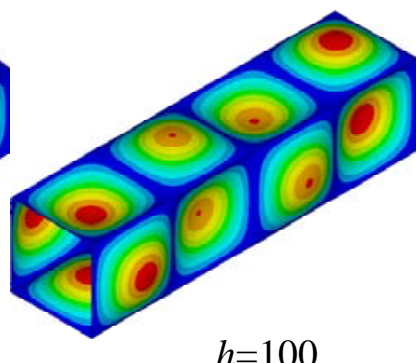

$h=100$

Fig. 5 Example of buckling mode by FEM $(l=400, b=100, h=30 \sim 100, t=1.0 \mathrm{~mm})$

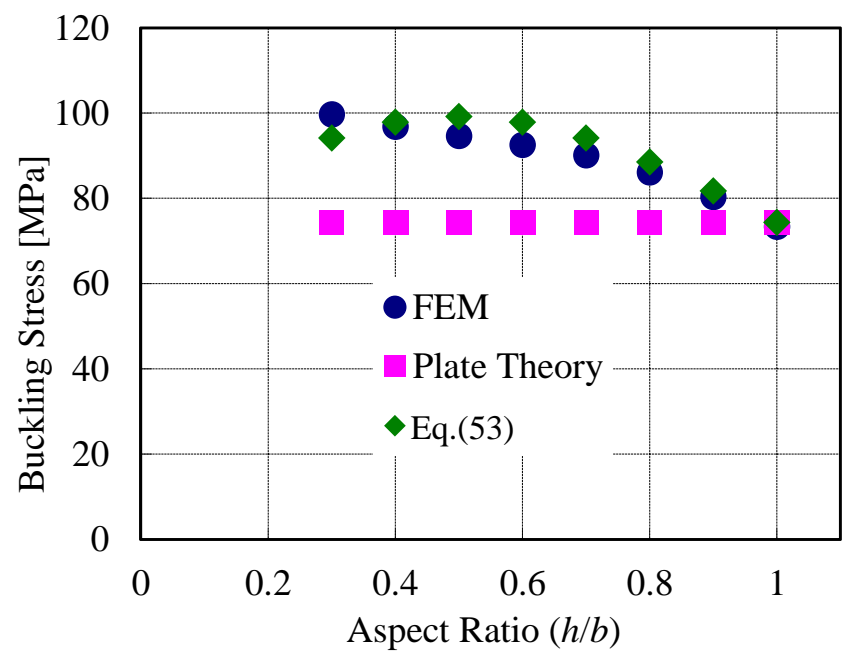

Fig. 6 Comparison of buckling stresses by FEM, and plate theory ( $l=400 \mathrm{~mm}, b=100, h=25 \sim 100, t=1.0$ ) 


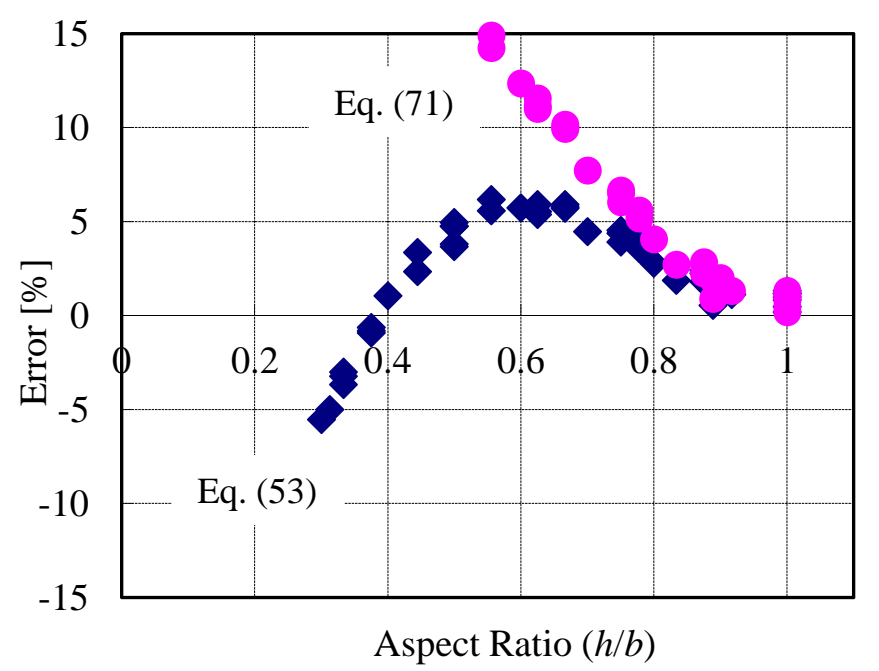

Fig. 7 Error distribution of shear buckling stress for aspect ratio of cross section

\section{$5 \cdot 2$ 座屈応力関係式と FEM 計算結果との比較}

本節では，圧縮とせん断の応力に関する 4 章に示した座屈応力関係式(74)と(75)と FEM 計算結果との比較を示 す．本節で FEM 計算を実施した箱形断面梁の構造諸元を表 2 に示すＦEM 計算における諸条件は前節と同じで ある。これらの箱形断面梁に対して，圧縮力とねじりトルクの比率を変化させて座屈固有值解析を実施した。た

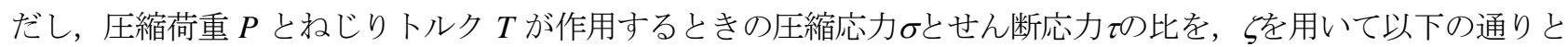
する.

$$
\sigma: \tau=(1-\zeta): \zeta=\frac{P}{2(b+h) t}: \frac{T}{2 b h t}
$$
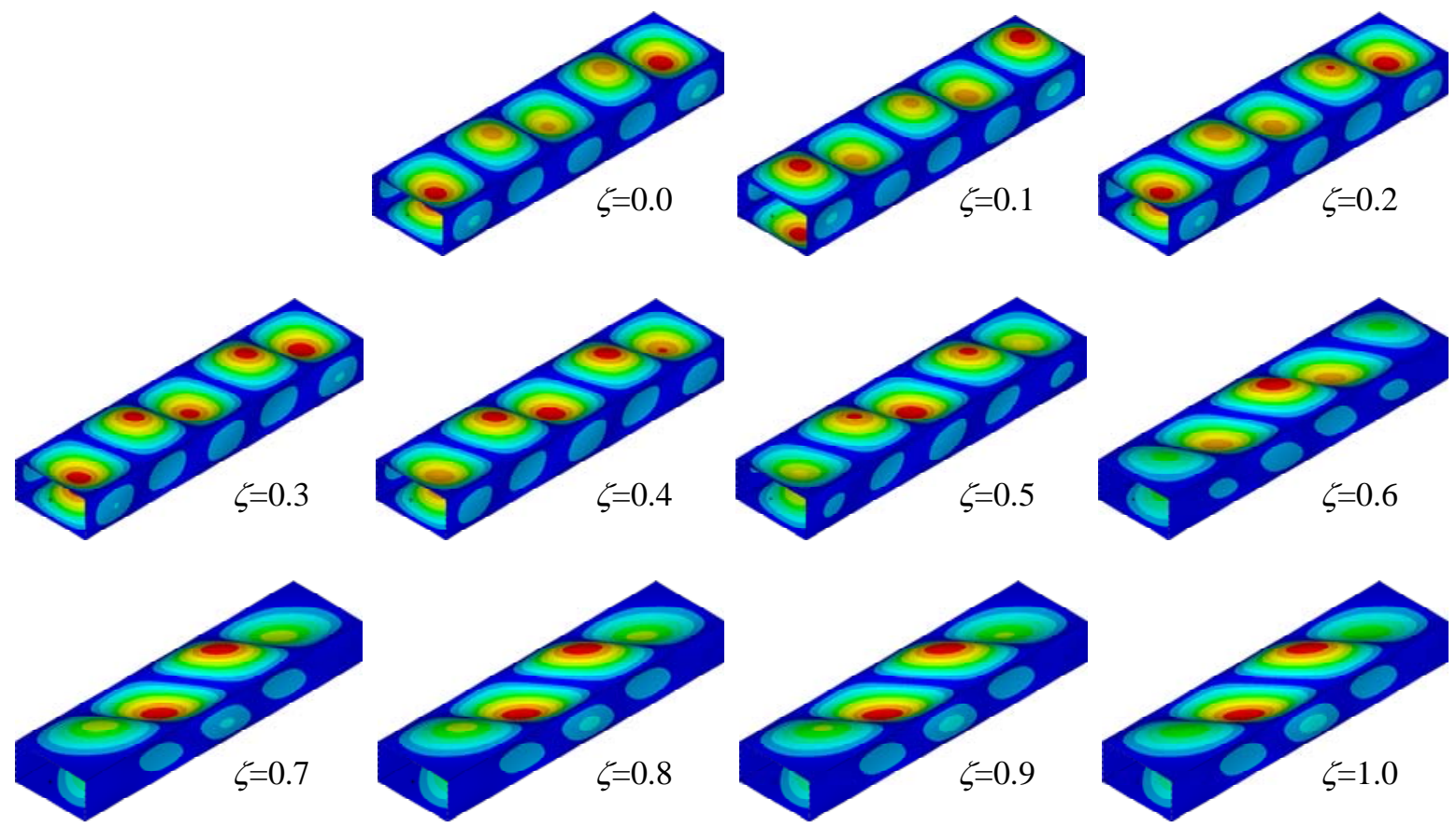

Fig. 8 Example of buckling mode by FEM $(l=400, b=100, h=50, t=1.0 \mathrm{~mm}, \zeta=0.0 \sim 1.0)$ 
$\zeta=0$ の時は純圧縮であり， $\zeta=1$ の時は純ねじり（純せん断）となる.

FEM 計算結果の一例として, 図 8 に $l=400, b=100, h=50, t=1.0 \mathrm{~mm}$ のときの座屈モードを, 図 9 に横軸を応 力の比率とした座屈応力の変化を示す. また, 寸べての FEM 計算結果と式(74)と(75)を図 10 に重ねて示す.

Table 2 Dimension of finite element model of box beam [mm]

\begin{tabular}{|r|r|r|c|}
\hline Length $(l)$ & Width $(b)$ & Thickness $(t)$ & Height $(h)$ \\
\hline 300 & 90 & 1.0 & $40,60,80$ \\
\hline 400 & 100 & 1.0 & $50,60,70,80,90$ \\
\hline 500 & 120 & 1.2 & 50,110 \\
\hline
\end{tabular}

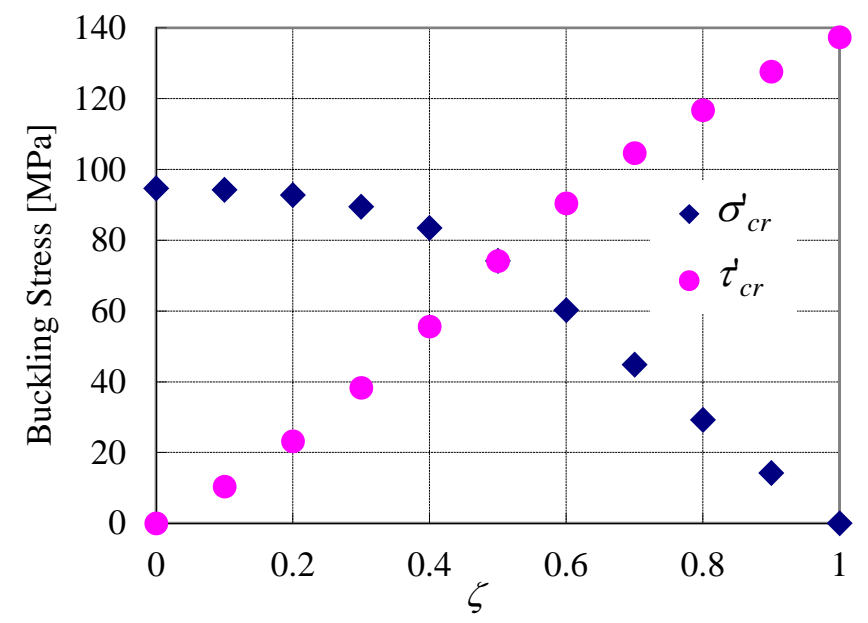

Fig. 9 Buckling stress along stress ratio by FEM

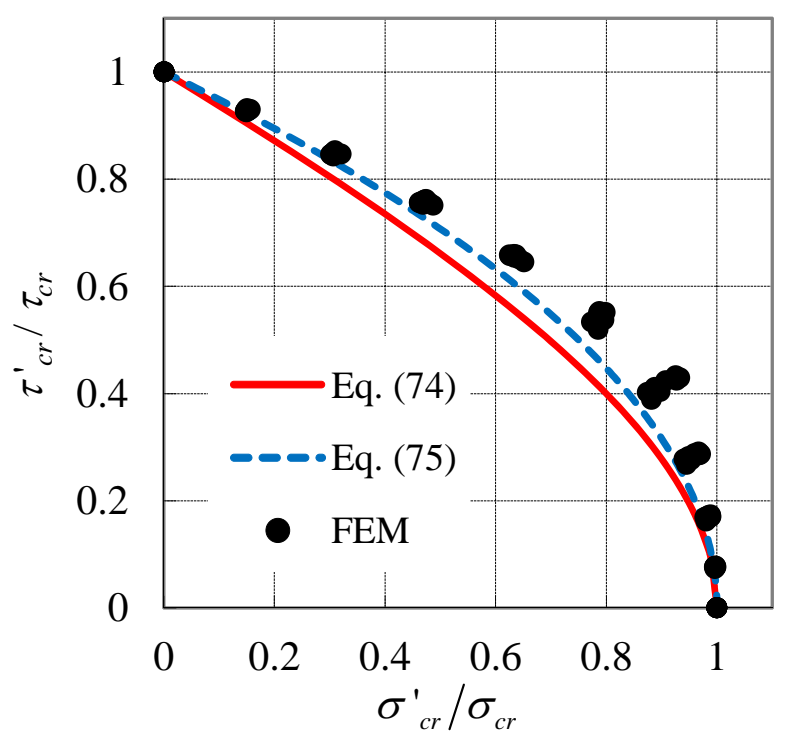

Fig. 10 Comparison of buckling stress relation equations with results from FEM

\section{$5 \cdot 3$ 座屈応力関係に関する考察}

図 10 からわかるように, FEM 計算結果に対しては, 式(74)より式(75)の方が近い結果となった. FEM 結果の式 (75)に対するずれを以下の通りに定義して, 図 11 に示す. 


$$
\operatorname{Diff}[\%]=\left[\frac{\sigma_{c r F E M}^{\prime}}{\sigma_{c r F E M}}+\left(\frac{\tau_{\text {crFEM }}^{\prime}}{\tau_{\text {crFEM }}}\right)^{2}-1\right] \times 100
$$

ただし， $\sigma_{c r F E M},{ }^{\prime} r F E M$ をそれぞれ FEM から求めた圧縮単独およびねじり単独の座屈応力とし， $\sigma_{c r F E M ， \tau_{c r F E M}}$ 圧縮とねじりが複合した場合の FEMから求めた座屈応力成分とする.

図 11 では応力比 $\zeta=0.5$ 近傍で式(75)との差が最も大きくなっている.また， $\zeta=0.4$ で差のばらつきが大きくなっ ている.このばらつきに関して寸法諸元との関係を検討したが，明確な関連性は見られなかった。本論文で対象 とした箱形断面梁に対しては式(75)がより近い值を示す結果となったが，それでも式(75)と FEM 計算結果とで最 大で 12\%ほどの差があり，式(75)で実用的な精度があるとは言い難い.

Ziemian（2010）の記述によれば，式(75)は Iguchi（1938）が求めた座屈応力の関係を回帰式として表したもの とされており, 式(75)の物理的意味を示す文献は見当たらない. 式(75)が平板の圧縮とせん断の理論解析值に対す る単なる回帰式であるとすれば，箱形断面梁の圧縮ねじり座屈の座屈応力関係式とは若干異なる可能性があると 解釈することもできる.

2 ・5 節で述べたように, 圧縮座屈応力の比とせん断座屈応力の比の関係式(74)および(75)は, パラメーター 用いて，以下の式で表すことができる.

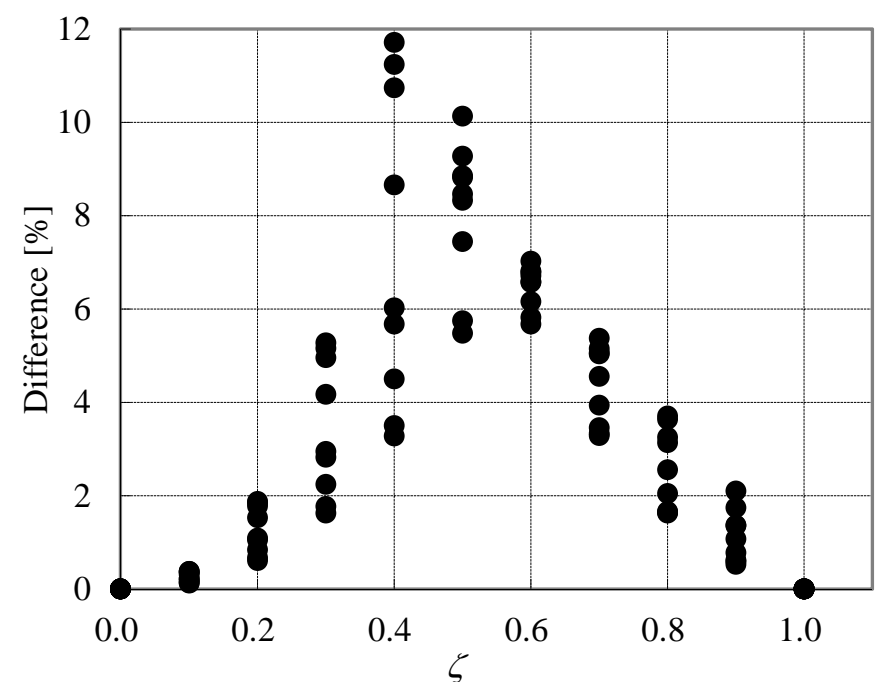

Fig. 11 Difference of stress ratio by Eq. (75) to results from FEM

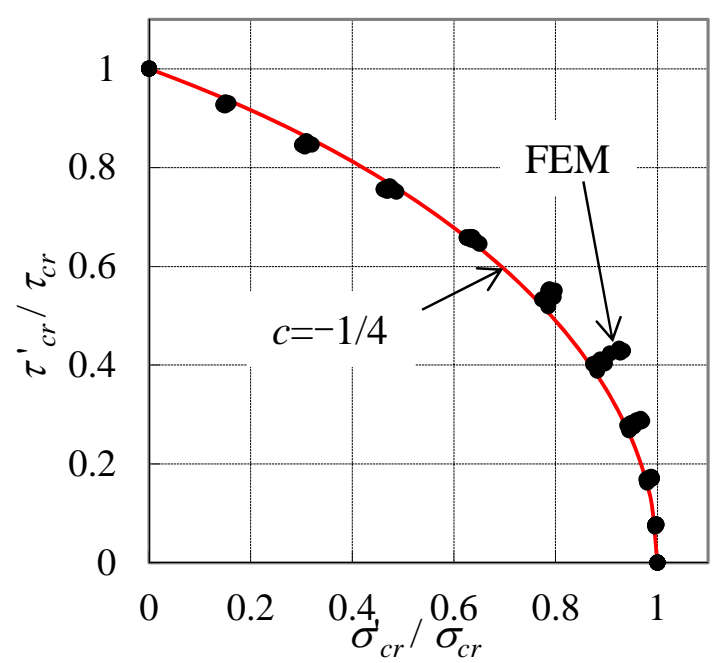

Fig. 12 Comparison of modified buckling relation equation with results from FEM 


$$
\left(1-\frac{\sigma_{c r}^{\prime}}{\sigma_{c r}}\right)\left(1-c \frac{\sigma_{c r}^{\prime}}{\sigma_{c r}}\right)-\left(\frac{\tau_{c r}^{\prime}}{\tau_{c r}}\right)^{2}=0
$$

上式で, $c=1 / 4$ とすれば式(74)となり, $c=0$ とすれば式(75)となる. 前節で示した箱形断面梁の圧縮ねじり座屈 に対しては，例えば $c=-1 / 4 （$ 最小自乗法により求めるならば， $c=-0.249 ）$ とすることによって, FEM 計算結果に 対して実用的な精度を有する関係式が得られる。 $c=-1 / 4$ の時の式(79)の曲線と FEM 計算結果を, 図 12 に重礼て 示寸.

すなわち，箱形断面梁の圧縮対じりと，平板の圧縮とせん断の座屈とは，上式で示したような類似性があり， それらの差異をパラメーターc の值の差として表せることを示している. ただし, 構造の差異や荷重条件の差に よって，どのような $c$ の值が適切か，構造諸元におけるどのパラメーターが c に影響するかに関する検討は，今 後の課題とする.

\section{6. 結言}

本論文では，まず単一平板の座屈応力関係式がエネルギー法に基づいて得られることを示した．次に，薄板で 構成された箱形断面梁に軸圧縮力とねじりトルクが複合する際に, 軸圧縮力に対する座屈応力の近似解を示すと 共に, 圧縮とねじりの座屈応力関係式を提案した。 そして, それらの提案した近似解および関係式の精度を FEM による座屈固有值解析で求められる結果と比較検証した。 その結果, 以下の結論を得た.

1. エネルギー法により得られる座屈固有方程式を低次数の項で近似することにより, 複合荷重時の平板の座屈 応力関係式を求めることができた. 得られた式のうち, 結果として公知の関係式と同じ式となる場合もあっ たが，異なる式となる場合もあった。しかし，それらの関係式には類似性があり，一つのパラメーターによ り関連づけることができることを示した。

2. 箱形断面梁の圧縮座屈応力は, 単一平板における座屈応力から求めることは精度が悪く, 隣接寸る板との連 成を考慮する必要がある. そこで, エネルギー法に基づいて求められる座屈の固有方程式から得られる知見 を基にし, かつ衫じり座屈における近似式を参考にして, 箱形断面梁の圧縮座屈応力を求める近似式を提示 した. FEMによる座屈固有值解析の結果と比較して, 得られた式は, 断面のアスペクト比が 0.3〜1 の間に おいて誤差はおよそ $6 \%$ 以内であり, 充分実用的な精度であることを確認した.

3. 箱形断面梁の圧縮ねじり座屈に対する座屈応力関係式を提示したが，FEM による結果とは最大で $12 \%$ 差 があった. このことから, 平板における圧縮せん断の座屈応力関係とは異なる式になる可能性が考えられる.

\section{文献}

AISI/CARS 2002, GAS (Geometric Analysis of Sections) (2002), American Iron and Steel Institute. 赤坂隆，吉田均，材料および構造技術者のための実用エネルギー法（2000），養賢堂.

CARS Automotive Steel Design Manual Revision 6.1 (2002), pp. 3.1-2, American Iron and Steel Institute.

Chwalla, E., Beitrag zur Stabilitatstheorie des Stegbleches vollwandiger Trager, Der Stahlbau (1936), pp. 161 - 166.

古巣克也，鶴見康昭，中川稔章，高木順，弾性座屈を考慮した梁の断面特性（薄板で構成された梁の有効幅理論 の検討)，第 14 回設計工学・システム部門講演会講演論文集，日本機械学会，No. 04-38 (2004), pp. 344-347. 古巣克也, 尼子龍幸, 鶴見康昭, 西垣英一, 弾性座屈を考慮した梁構造物の剛性解析, 第 16 回設計工学・シ ステム部門講演会講演論文集，日本機械学会，No．06-33 (2006)， pp. 162-164.

古巣克也, 尼子龍幸, 中川稔章, 竹田英生, 浜辺勉, 張力場を考慮した長方形平板のせん断座屈後挙動, 日 本機械学会, M\&M2011 カンファレンス (2011), OS2315.

古巣 克也, 尼子 龍幸, 中川 稔章, 竹田 英生, 浜辺 勉, 長方形平板のせん断座屈後挙動, 日本機械学会論文 集 A編, Vol. 78, No. 786 (2012a), pp.171-178.

古巣克也, 尼子龍幸, 中川稔章, 浜辺勉, 青木典久, 圧縮とせん断が複合した長方形平板の座屈に関する一考察, 日本機械学会, M\&M2012 カンファレンス (2012b), GS49.

古巣克也, 尼子龍幸, 中川稔章, 浜辺勉, 青木典久, 箱形断面梁のねじり座屈の近似解法”, 日本機械学会論文 集 A編, Vol. 79, No. 801 (2013a), pp.573-581. 
古巣克也, 尼子龍幸, 中川稔章, 浜辺勉, 青木典久, 箱形断面梁のねじり座屈の近似解法に関する一考察, 日本 機械学会，M\&M2013 カンファレンス (2013b)，GS34.

林毅編，軽構造の理論とその応用（上） (1966), p.194, JUSE 出版社.

Iguchi, S., Die Knickung der rechtechckigen Platte durch Schubkraft, Ingenieur Archiv, vol. 9 (1938), pp. 1- 12.

Johnson, A. E. Jr. and Buchert, K. P., Critical combinations of bending, shear, and transverse compressive stresses for buckling of infinitely long flat plates, NACA Technical Note 2536 (1951).

von Karman, T., Sechler, E. E. and Donnell, L. H., "The strength of thin plates in compression”, Transactions ASME, Vol. 54 (1932), pp. 53-56.

Nishigaki, H., Nishiwaki, S., Amago, T., Kojima, Y. and Kikuchi, N., First order analysis - New CAE tools for automotive body designers, SAE Technical Paper No. 2001-01-0768 (2001).

Timoshenko, S. P., Theory of elastic stability, Second Edition (1961), p.379, McGraw-Hill Book Company, Inc.

土木学会鋼構造委員会編(委員長 宇佐美勉), 座屈設計ガイドライン, 鋼構造シリーズ 12 (2005), p. 198, 丸善.

Yu, W.-W., COLOD-FORMED STEEL DESIGN, 3rd Edition (2000), p.89, JOHN WILEY \& SONS, INC.

Ziemian , R. D. ed., Guide to Stability Design Criteria for Metal Structures, Sixth Edition (2010), pp. 128 - 145, JOHN WILEY \& SONS, INC.

\section{References}

AISI/CARS 2002, GAS (Geometric analysis of sections) (2002), American Iron and Steel Institute.

Akasaka, T. and Yoshida, H., Zairyo oyobi kozo gijutsusha no tameno jitsuyo enerugiho (2000), Youkendou.

CARS Automotive Steel Design Manual Revision 6.1 (2002), pp. 3.1-2, American Iron and Steel Institute.

Chwalla, E., Beitrag zur Stabilitatstheorie des Stegbleches vollwandiger Trager, Der Stahlbau (1936), pp. 161 - 166 (in German).

Furusu, K., Tsurumi, Y., Nakagawa, T. and Takagi, J., Section property of the beam considering elastic buckling -Study of effective width theory for beam section composed of thin plate-, Proceedings of 14th Design \& Systems Conference '04 of the Japan Society of Mechanical Engineers, No. 04-38 (2004), pp. 344-347 (in Japanese).

Furusu, K., Amago, T., Tsurumi, Y. and Nishigaki, H., Stiffness analysis of beam structure considering elastic buckling, Proceedings of 16th Design \& Systems Conference '06 of the Japan Society of Mechanical Engineers, No. 06-33 (2006), pp. 162-164 (in Japanese).

Furusu, K., Amago, T., Nakagawa, T., Takeda, H. and Hamabe, T., Post-buckling behavior of rectangular plate under shear in consideration of tension field, Mechanics of Materials Conference M\&M2011 of the Japan Society of Mechanical Engineers (2011), OS2315 (in Japanese).

Furusu, K., Amago, T., Nakagawa, T., Takeda, H. and Hamabe, T., Post-buckling behavior of rectangular plate under shear, Transactions of the Japan Society of Mechanical Engineers, Series A, Vol. 78, No. 786 (2012a), pp. 171-178 (in Japanese).

Furusu, K., Amago, T., Nakagawa, T., Hamabe, T. and Aoki, N., A study on the buckling of a rectangular plate under compression and shear stress, Mechanics of Materials Conference M\&M2012 of the Japan Society of Mechanical Engineers (2012b), GS49 (in Japanese).

Furusu, K., Amago, T., Nakagawa, T., Hamabe, T. and Aoki, N., Approximate solution of torsional buckling of box beam, Transactions of the Japan Society of Mechanical Engineers, Series A, Vol. 79, No. 801 (2013a), pp. 573-581 (in Japanese).

Furusu, K., Amago, T., Nakagawa, T., Hamabe, T. and Aoki, N., A study on approximate solution of torsional buckling of box beam, Mechanics of Materials Conference M\&M2013 of the Japan Society of Mechanical Engineers (2013b), GS34 (in Japanese).

Hayashi, T. ed., Keikouzou no riron to sono ouyou (jou) (1966), p.194, JUSE Shuppansha (in Japanese).

Iguchi, S., Die Knickung der rechtechckigen Platte durch Schubkraft, Ingenieur Archiv, vol. 9 (1938), pp. 1 - 12 (in German).

Johnson, A. E. Jr. and Buchert, K. P., Critical combinations of bending, shear, and transverse compressive stresses for buckling of infinitely long flat plates, NACA Technical Note 2536 (1951).

von Karman, T., Sechler, E. E. and Donnell, L. H., The strength of thin plates in compression, Transactions ASME, Vol. 54 (1932), pp. 53-56. 
Nishigaki, H., Nishiwaki, S., Amago, T., Kojima, Y. and Kikuchi, N., First order analysis - New CAE tools for automotive body designers, SAE Technical Paper No. 2001-01-0768 (2001).

Timoshenko, S. P., Theory of elastic stability, Second Edition (1961), p.379, McGraw-Hill Book Company, Inc.

Usami, T. ed., Guidelines for stability design of steel structures $2^{\text {nd }}$ Edition, Steel Structures Series 12, published by Subcommittee on Stability Design Committee on Steel Structures, Japan Society of Civil Engineers (2005), p. 198, Maruzen (in Japanese).

Yu, W.-W., COLOD-FORMED STEEL DESIGN, 3rd Edition (2000), p.89, JOHN WILEY \& SONS, INC.

Ziemian , R. D. ed., Guide to stability design criteria for metal structures, $6^{\text {th }}$ Edition (2010), pp. 128-145, JOHN WILEY \& SONS, INC. 